\section{Effect of Soil Carbon on Phytotoxicity of Topramezone-treated Irrigation Water to St. Augustinegrass}

\author{
Carl J. Della Torre III ${ }^{1}$, William T. Haller ${ }^{1}$, and Lyn A. Gettys ${ }^{2,3}$
}

ADDITIONAL INDEX WORDs. irrigation restrictions, nontarget effects, Oasis ${ }^{\circledR}$, aquatic herbicide, organic matter, $K_{\mathrm{oc}}$

SumMARY. Topramezone is a 4-hydroxyphenylpyruvate dioxygenase (HPPD)inhibiting herbicide that was labeled for aquatic use in Florida in 2013 with a maximum submersed application concentration of $50 \mu \mathrm{g} \cdot \mathrm{L}^{-1}$. Preliminary greenhouse studies reported that the concentration of herbicide that reduces growth by $10 \%$ compared with untreated controls $\left(\mathrm{EC}_{10}\right)$ of topramezone in irrigation water applied to st. augustinegrass (Stenotaphrum secundatum) grown in $100 \%$ sand was $3.5 \mathrm{ppb}$. The objective of these experiments was to determine whether substrate carbon content influenced the response of 'Palmetto' st. augustinegrass to irrigation with topramezone-treated water. The herbicide was applied at concentrations ranging from 0 to $120 \mathrm{ppb}$ to mature plants grown in 7.5inch-diameter nursery containers. Pots were filled with washed masonry sand amended with one of five carbon contents: $0 \%, 0.3 \%, 0.6 \%, 1.5 \%$, and $4.0 \%$. Plants were irrigated twice weekly for 4 weeks with topramezone-containing water and grown out for 12 weeks after the final topramezone treatment to evaluate possible recovery from any herbicide damage. Plant material was clipped as needed for a total of eight harvests and each harvest was dried and weighed. $\mathbf{E C}_{10}$ values for 'Palmetto' st. augustinegrass grown in substrates with $0 \%, 0.3 \%, 0.6 \%, 1.5 \%$, and $4.0 \%$ carbon were $3.7,7.3,10.1,28.1$, and $25.7 \mathrm{ppb}$, respectively. These experiments revealed that substrate carbon content has a noteworthy effect on the susceptibility of 'Palmetto' st. augustinegrass to topramezone in irrigation water. However, regular irrigation with water containing high concentrations of topramezone is likely to cause damage to 'Palmetto' st. augustinegrass in Florida's sandy soils.

S we augustinegrass is the most widely used turfgrass in commercial and home landscapes in Florida and is also a commonly used turfgrass along the coastal Gulf states. It grows throughout the year in southern Florida but usually senesces

This research was supported by the Florida Agricultural Experiment Station and by the United States Department of Agriculture National Institute of Food and Agriculture (HATCH project FLA-FTL005156). Partial funding was provided by the Florida Fish and Wildlife Conservation Commission Graduate Student Mini-Grant (FY 2013-14).

We extend our appreciation to Mark Brenner and Jason Curtis (Department of Geological Sciences, University of Florida) for performing the soil carbon analyses. We thank Rhett Gehring and Jon Gosselin for assistance with planting, harvesting, and data collection.

Mention of a trademark, proprietary product, or vendor does not constitute a guarantee or warranty of the product and does not imply its approval to the exclusion of other products or vendors that also may be suitable.

${ }^{1}$ Center for Aquatic and Invasive Plants, Institute of Food and Agricultural Sciences (IFAS), University of Florida, 7922 NW 71 Street, Gainesville, FL 32653

${ }^{2}$ Fort Lauderdale Research and Education Center, IFAS, University of Florida, 3205 College Avenue, Davie, FL 33314

${ }^{3}$ Corresponding author. E-mail: lgettys@ufl.edu.

https://doi.org/10.21273/HORTTECH03858-17 during the winter in the northern range of its distribution. St. augustinegrass is established vegetatively by planting sod, plugs, or sprigs, which under ideal conditions, rapidly expand to form a dense groundcover via extensive stoloniferous growth. Once established, st. augustinegrass should be irrigated with $0.5-0.75$ inch of water two to three times per week if no rainfall occurs (Trenholm et al., 2017). Irrigation water sources vary based on site conditions and availability and may include municipal waters, private wells, and ponds located on-site. Mowing frequency and height vary among cultivars, but growth and pest resistance are optimized when st. augustinegrass is maintained at a height of 2.5-4 inches (Trenholm et al., 2014).

Topramezone is a carotenoid biosynthesis inhibitor that interferes with the production of the enzyme HPPD in the carotenoid pigment synthesis pathway (Senseman, 2007). In addition to its recent registration for aquatic weed control, topramezone is used for weed control in upland systems. For example, Armezon (336 g. $\mathrm{L}^{-1}$ topramezone; BASF, Research Triangle Park, NC) is labeled at application rates of up to $25 \mathrm{~g} \cdot \mathrm{ha}^{-1}$ for postemergence control of grasses and broadleaf weeds in corn (BASF, 2012) and Pylex (336 g. $\mathrm{L}^{-1}$ topramezone; BASF) is labeled for weed control at rates up to $50 \mathrm{~g} \cdot \mathrm{ha}^{-1}$ in cool-season turfgrasses such as golf courses, sod farms, and residential landscapes (BASF, 2015). The Pylex label specifically states that applications will control or suppress st. augustinegrass, bahiagrass (Paspalum notatum), and bermudagrass (Cynodon dactylon) (BASF, 2015). The herbicide Frequency $^{\circledR}$ (336 $\mathrm{g} \cdot \mathrm{L}^{-1}$ topramezone; BASF) is labeled for use in pine plantations, rights of way, and other noncrop sites (BASF, 2013). Grasses listed as tolerant of topramezone include cool-season grasses such as bluestem (Andropogon sp.), fescue (Festuca sp.), bluegrass (Poa sp.), and centipedegrass (Eremochloa sp.).

Topramezone was studied for several years under an experimental use permit to evaluate its efficacy on the submersed aquatic weed hydrilla (Hydrilla verticillata). Puri et al. (2009) found that topramezone provided effective control of hydrilla at concentrations of $25-40 \mu \mathrm{g} \cdot \mathrm{L}^{-1}$; it was highly selective at these rates and caused little damage to most

\begin{tabular}{llll}
\hline $\begin{array}{l}\text { Units } \\
\begin{array}{l}\text { To convert U.S. to SI, } \\
\text { multiply by }\end{array}\end{array}$ & U.S. unit & SI unit & $\begin{array}{l}\text { To convert SI to U.S., } \\
\text { multiply by }\end{array}$ \\
\hline 1.0432 & $\mathrm{fl} \mathrm{oz} / \mathrm{oz}$ & $\mathrm{mL} \cdot \mathrm{g}^{-1}$ & 0.9586 \\
2.54 & inch $(\mathrm{es})$ & $\mathrm{cm}$ & 0.3937 \\
25.4 & inch $(\mathrm{es})$ & $\mathrm{mm}$ & 0.0394 \\
0.4536 & $\mathrm{lb}$ & $\mathrm{kg}$ & 2.2046 \\
28.3495 & $\mathrm{oz}$ & $\mathrm{g}$ & 0.0353 \\
70.0532 & $\mathrm{oz} / \mathrm{acre}$ & $\mathrm{g} \cdot \mathrm{ha}^{-1}$ & 0.0143 \\
7.4892 & $\mathrm{oz} / \mathrm{gal}$ & $\mathrm{g} \cdot \mathrm{L}^{-1}$ & 0.1335 \\
1 & $\mathrm{ppb}$ & $\mu \mathrm{g} \cdot \mathrm{L}^{-1}$ & 1 \\
1 & $\mathrm{ppm}$ & $\mathrm{mg} \cdot \mathrm{L}^{-1}$ & 1 \\
$\left({ }^{\circ} \mathrm{F}-32\right) \div 1.8$ & ${ }^{\circ} \mathrm{F}$ & ${ }^{\circ} \mathrm{C}$ & $\left({ }^{\circ} \mathrm{C} \times 1.8\right)+32$
\end{tabular}


native nontarget plants. It was registered for aquatic use by the U.S. Environmental Protection Agency in 2013 under the trade name Oasis (SePRO Corp., Carmel, IN). Because irrigation water is sometimes sourced from on-site ponds that may also be targeted for aquatic weed control, determining whether aquatic herbicides have phytotoxic effects on irrigated landscape plants such as st. augustinegrass is of interest. Previous greenhouse studies evaluating the effect of topramezone in irrigation water revealed that the $\mathrm{EC}_{10}$ of topramezone was $3.5 \mathrm{ppb}$ on 'Palmetto' st. augustinegrass grown in $100 \%$ sand (Haller et al., 2017). However, these results differed from unpublished field observations; plants used in greenhouse studies are typically grown in sand to determine phytotoxicity of herbicides in the absence of soil carbon, whereas most field soils where turfgrasses are grown contain carbon, which can bind with topramezone. The soil adsorption coefficient $\left(K_{\mathrm{oc}}\right)$ of topramezone is $22-172$ $\mathrm{mg} \cdot \mathrm{L}^{-1}$, with a soil half-life of $14 \mathrm{~d}$ and a reported half-life of $72 \mathrm{~d}$ in water (Shaner, 2014). Soil half-life or degradation of a potentially phytotoxic herbicide is very relevant when the chemical is applied multiple times at sublethal doses such as may occur via herbicide-treated irrigation water. Depending on the half-life of a product, multiple irrigation events may add to the soil burden of the herbicide and eventually result in phytotoxic concentrations. The objective of these experiments was to determine the effects of irrigation with topramezone-treated water on 'Palmetto' st. augustinegrass grown in substrates with different carbon contents.

\section{Materials and methods}

Commercially available topsoil [a regionally formulated mix of organic and mineral components (Margo Garden Products, Folkston, GA)] was purchased from a local garden supply retailer, air-dried and sieved through a 3-mm-mesh screen to remove coarse particles and collect the fine organic/sand fraction. This fraction was then mixed with washed sand [grain diameter $0.25-0.5 \mathrm{~mm}$ (Sakrete Multi-Purpose Sand; Sakrete, Charlotte, NC)] in a cement mixer in proportions $\approx 0 \%$ (pure sand), $0.5 \%, 1 \%, 2 \%$, and $4 \%$ organic matter by weight. Random samples of the substrate mixtures (hereafter "mixes") were collected and analyzed to determine the carbon content of each mix. Organic carbon content (percent) was determined for five random samples of each mix using an elemental analyzer to separate nitrogen and carbon dioxide gases, which were quantified using a thermal conductivity detector (Stable Isotope Mass Spectrometry Laboratory, Department of Geological Sciences, University of Florida, Gainesville, FL).

'Palmetto' st. augustinegrass sod was purchased from a local garden supply retailer in Gainesville, FL. A hatchet was used to cut the sod into 7.5-inch-diameter rounds using a plastic pipe as a guide. All soil, dead vegetation, organic matter, and other materials were washed from the roots; these washed sod pieces were then planted into 7.5-inch-diameter nursery containers filled to 0.5 inch below the top of the pot with one of the five mixes. This gap was left to ensure that future irrigation solutions would remain in the pots. Each nursery container held $2.6 \mathrm{~kg}$ of dried mix; before planting, the mix in each pot was amended with $5.2 \mathrm{~g}$ of $15 \mathrm{~N}-$ 3.9P-9.9K controlled-release fertilizer (Osmocote Plus; ICL Specialty Fertilizers, Dublin, $\mathrm{OH}$ ), the low incorporation rate on the fertilizer label. Forty pots of each mix were planted with 'Palmetto' st. augustinegrass and cultured under natural daylength (11$12.5 \mathrm{~h}$ light) in a greenhouse equipped with propane heaters and an evaporative cooling system; average night and day air temperatures ranged from 16 to $30^{\circ} \mathrm{C}$, respectively, throughout the duration of the experiments. Plants were irrigated as needed during an initial establishment period ( 3 to 4 weeks) to obtain active growth. When plants were well established, 30 pots of each mix were selected for uniformity of growth and were randomly assigned to receive different concentrations of topramezone in irrigation water.

Stock solutions of a commercial formulation of $336 \mathrm{~g} \cdot \mathrm{L}^{-1}$ topramezone $\left(\right.$ Oasis $^{\circledR}$ ) were made every week and were added to irrigation water to achieve concentrations of $0,7.5,15$, 30 , 60, and $120 \mathrm{ppb}$ of topramezone. Five replications of each carbon content/topramezone concentration combination were prepared. St. augustinegrass was irrigated at 0.5 inch every 4 to $5 \mathrm{~d}$ with one of the topramezone irrigation treatments from 5 Dec. 2013 to 10 Jan. 2014. Clippings were collected at a mowing height of 1.5 inches, dried at $90{ }^{\circ} \mathrm{C}$, and mass recorded about every 2 weeks. At the end of the $36 \mathrm{~d}$ for the topramezone irrigation treatments, st. augustinegrass growth was assessed for an additional $77 \mathrm{~d}$ to characterize plant recovery from herbicide-induced damage. During this time, soil moisture was evaluated daily by inserting a finger into the substrate to a depth of $\approx 1$ inch; if the soil was dry, the plants were irrigated with untreated water as needed. Dry biomass data from all harvests of each replication were pooled to represent cumulative experiment-long biomass production per replication and were subjected to analysis of variance and nonlinear regression using SAS (version 9.3; SAS Institute, Cary, NC). Regression models were used to calculate $\mathrm{EC}_{10}$ values for each carbon content. The $\mathrm{EC}_{10}$ value is conservative and was selected to represent the level at which herbicide damage might become noticeable to a homeowner (Koschnick et al., 2005).

In addition to periodic harvests of grass clippings, visual evaluations were conducted twice during these experiments to provide a qualitative evaluation of the level of damage to 'Palmetto' st. augustinegrass to determine whether plants would exhibit additional damage or recover after irrigation with topramezone-treated water was discontinued. Plants were assigned a score ranging from 0 to 4 as follows: $0=$ no effect, $1=$ slight effect $(<10 \%$ leaves with symptoms), 2 = obvious symptoms ( $10 \%$ to $50 \%$ leaves bleached), $3=$ very obvious reduced growth (all leaves affected), $4=$ all leaves necrotic

\section{Results and discussion}

Target organic carbon concentrations based on dry weight ratios of organic matter and sand were $0 \%$, $0.5 \%, 1 \%, 2 \%$, and $4 \%$ organic carbon. However, instrumental analyses revealed that actual carbon contents $( \pm \mathrm{SE})$ were $>0.01 \% \pm 0.00 \%, 0.3 \% \pm$ $0.03 \%, 0.6 \% \pm 0.03 \%, 1.5 \% \pm 0.10 \%$, and $4.0 \% \pm 0.29 \%$. Dry weights of 'Palmetto' st. augustinegrass clippings harvested eight times over the 
course of this 113-d experiment (eight irrigations with water containing 15,30 , or $60 \mathrm{ppb}$ topramezone over a 36-d period, followed by a 77-d grow out period) are presented in Figs. 1-3. These data are provided in detail because these concentrations are similar to the labeled treatment concentrations of up to $50 \mathrm{ppb}$ topramezone allowed for submersed aquatic weed control.

Figure 1 shows individual harvest and cumulative dry weights of 'Palmetto' st. augustinegrass clippings harvested during and after irrigation with $15 \mathrm{ppb}$ topramezone. Soil carbon content had no effect on dry weight in the first three harvests, but dry weights of 'Palmetto' st. augustinegrass grown in substrate with $0 \%$ or $0.3 \%$ carbon content were lower than those of plants grown in mixes with higher carbon contents in harvests 4-7. These differences were no longer significant by the final harvest (after the 77 - $d$ grow out period), indicating that plants recovered from the eight 0.5 -inch irrigations with $15 \mathrm{ppb}$ topramezone. This recovery is also evident in visual ratings recorded on day 36 (last irrigation with topramezonetreated water) and day 113 (end of the 77 -d grow out period) (Table 1 ). Visual quality of 'Palmetto' st. augustinegrass grown in substrates with $0 \%$ carbon and irrigated with $15 \mathrm{ppb}$ topramezone was significantly lower (rating 3) than plants grown in mixes with higher carbon contents on day 36 , but this difference was no longer evident by day 113 (end of the $77-\mathrm{d}$ grow out period). Despite this recovery, cumulative harvest dry weights for plants grown in substrates with soil carbon contents of $0 \%$ or $0.3 \%$ and irrigated with $15 \mathrm{ppb}$ topramezone were lower than plants grown in mixes with higher soil carbon contents (Fig. 1).

Dry weights of 'Palmetto' st. augustinegrass irrigated with $30 \mathrm{ppb}$ topramezone are presented in Fig. 2. There were minor differences in dry weight of plants grown in substrates with different carbon contents during the first two harvests, but differences in dry weight of plants grown in substrates with soil carbon contents of $0 \%$ or $0.3 \%$ became more pronounced in later harvests. Analysis of cumulative biomass data revealed that irrigation with topramezone at $30 \mathrm{ppb}$ reduced growth by $>70 \%$ when plants were

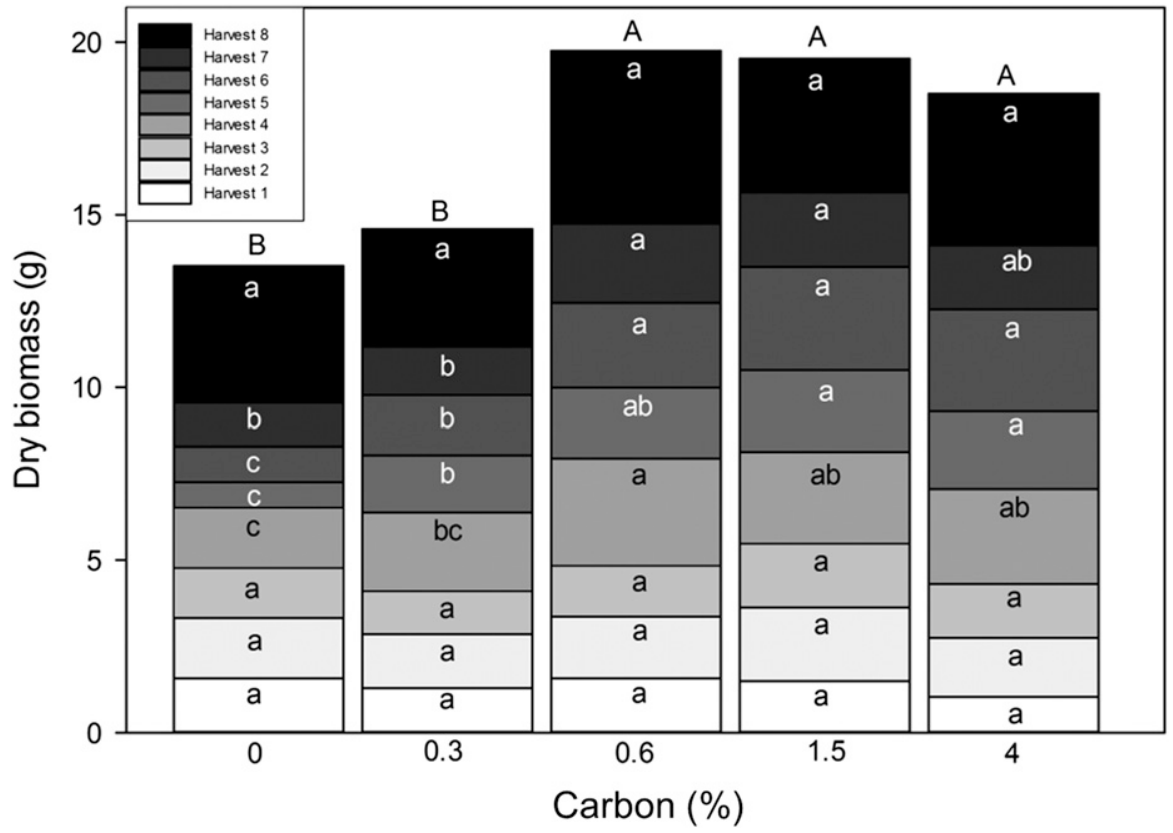

Fig. 1. Dry biomass of each harvest and cumulative dry weight of 'Palmetto' st. augustinegrass grown in sand amended with $0 \%, 0.3 \%, 0.6 \%, 1.5 \%$, or $4 \%$ carbon and irrigated eight times over a $36-\mathrm{d}$ period with $15 \mathrm{ppb}$ topramezone, followed by a 77-d grow out period to evaluate delayed effects. Grass clippings were collected about every 2 weeks during the 117 -d study period. Bars represent the mean of five replications per treatment, and treatments coded with the same letter are not different at $\boldsymbol{P}=\mathbf{0 . 0 5}$ least significant difference; lowercase $=$ differences within an individual harvest, uppercase $=$ differences in cumulative effects; $1 \mathrm{ppb}=$ $1 \mu \mathrm{g} \cdot \mathrm{L}^{-1}, 1 \mathrm{~g}=0.0353 \mathrm{oz}$.

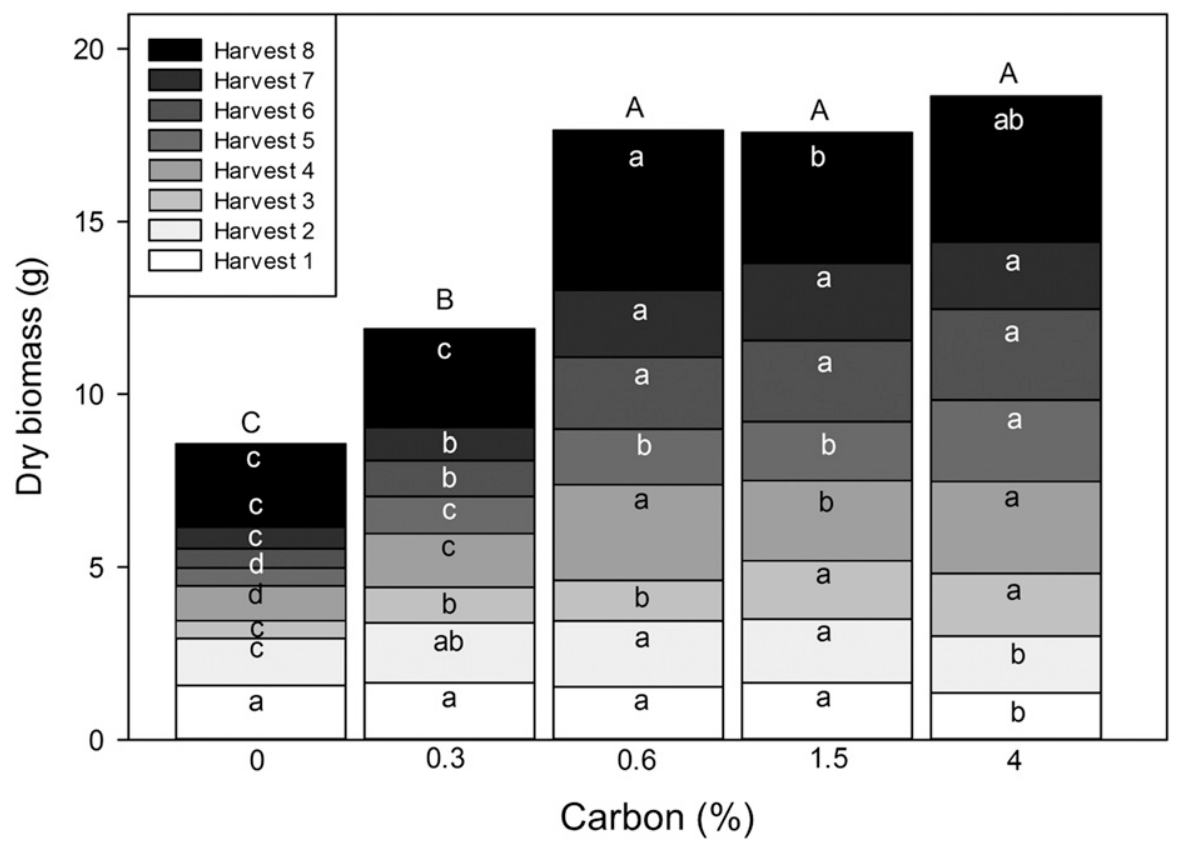

Fig. 2. Dry biomass of each harvest and cumulative dry weight of 'Palmetto' st. augustinegrass grown in sand amended with $0 \%, 0.3 \%, 0.6 \%, 1.5 \%$, or $4 \%$ carbon and irrigated eight times over a $36-\mathrm{d}$ period with $30 \mathrm{ppb}$ topramezone, followed by a 77-d grow out period to evaluate delayed effects. Grass clippings were collected about every 2 weeks during the 117-d study period. Bars represent the mean of five replications per treatment, and treatments coded with the same letter are not different at $\boldsymbol{P}=\mathbf{0 . 0 5}$ least significant difference; lowercase $=$ differences within an individual harvest, uppercase = differences in cumulative effects; 1 ppb = $1 \mu \mathrm{g} \cdot \mathrm{L}^{-1}, 1 \mathrm{~g}=0.0353 \mathrm{oz}$. 
grown in substrate with no carbon and by $\approx 30 \%$ in mixes with $0.3 \%$ carbon, whereas soil carbon contents of $0.6 \%$ or higher appeared to have a protective effect on 'Palmetto' st. augustinegrass irrigated with topramezone at this concentration. Dry weights recorded during the final harvest [day 113 (end of the 77-d grow out period)] were lower for plants grown in substrates with $0 \%$ or $0.3 \%$ carbon than for plants grown in mixes with higher carbon contents, but were higher than the dry weights recorded for the same plants during harvests 37 , which suggests recovery during the 77 -d grow out period. Visual quality of plants grown in substrates with $\leq 0.6 \%$ carbon and irrigated with 30 ppb topramezone was reduced on day 36 , but complete recovery (no reduction in quality) of plants grown in mixes with carbon contents of $0.3 \%$ or higher was evident by day 113 (Table 1). 'Palmetto' st. augustinegrass grown in substrate without

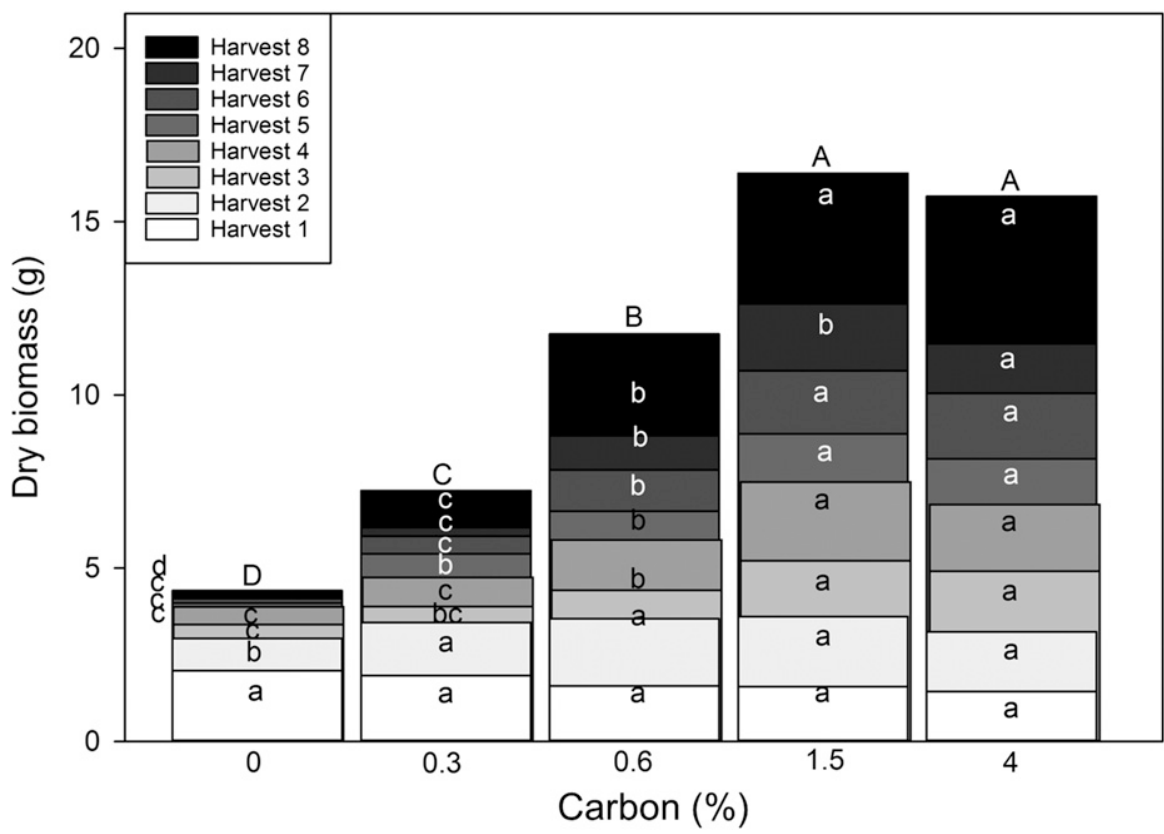

Fig. 3. Dry biomass of each harvest and cumulative dry weight of 'Palmetto' st. augustinegrass grown in sand amended with $0 \%, 0.3 \%, 0.6 \%, 1.5 \%$, or $4 \%$ carbon and irrigated eight times over a $36-\mathrm{d}$ period with $60 \mathrm{ppb}$ topramezone, followed by a 77-d grow out period to evaluate delayed effects. Grass clippings were collected about every 2 weeks during the 117-d study period. Bars represent the mean of five replications per treatment, and treatments coded with the same letter are not different at $\boldsymbol{P}=\mathbf{0 . 0 5}$ least significant difference; lowercase $=$ differences within an individual harvest, uppercase $=$ differences in cumulative effects; 1 ppb = $1 \mu \mathrm{g} \cdot \mathrm{L}^{-1}, 1 \mathrm{~g}=0.0353 \mathrm{oz}$. carbon was severely damaged by day 36 and showed only slight recovery by day 113 (Table 1 ).

Individual harvest and cumulative dry weights of 'Palmetto' st. augustinegrass grown in substrates with $0 \%$ to $4.0 \%$ carbon and irrigated with $60 \mathrm{ppb}$ topramezone are presented in Fig. 3. Similar to data from the $30 \mathrm{ppb}$ treatments, differences in dry weights were minor during the first two harvests and more dramatic in subsequent harvests, when dry weights were lower in plants grown in mixes with $\leq 0.6 \%$ carbon. With the exception of harvest 7 , there were no differences in individual or cumulative dry weights of plants grown in substrates with soil carbon contents of $1.5 \%$ or $4.0 \%$. Dry weight and quality of plants grown in mixes with $0.3 \%$ or $0.6 \%$ carbon was reduced and only slight recovery occurred during the 77-d grow out period, whereas plants grown in substrate with no carbon were severely affected and had little or no live biomass by day 113 (Table 1).

The moderating effect of soil carbon on topramezone phytotoxicity to 'Palmetto' st. augustinegrass is evident in Fig. 4, which includes calculated $\mathrm{EC}_{10}$ values and summarizes the effect of the six herbicide concentrations applied to plants grown in the five substrate mixes. Plants grown in substrate with no organic carbon and irrigated with $7.5 \mathrm{ppb}$ topramezone concentrations had reduced growth compared with untreated controls that were irrigated with well water. The $\mathrm{EC}_{10}$ calculated from the cumulative harvest data for this treatment was $3.7 \mathrm{ppb}$ (range 3.1-4.7 ppb), which agrees well with

Table 1. Soil carbon of five substrate mixes and visual quality of st. augustinegrass irrigated eight times over a 36-d period with $0,7.5,15,30,60$, or $120 \mathrm{ppb}$ topramezone. Values represent the mean of five replications per treatment.

\begin{tabular}{|c|c|c|c|c|c|c|c|c|c|c|c|c|}
\hline \multirow{3}{*}{$\begin{array}{l}\text { Evaluation date } \mathrm{y}^{\mathrm{y}} \\
\text { Soil carbon }[\text { mean } \pm \text { SE }(\%)]\end{array}$} & \multicolumn{12}{|c|}{ Topramezone $(p p b)^{z}$} \\
\hline & \multicolumn{2}{|c|}{0} & \multicolumn{2}{|c|}{7.5} & \multicolumn{2}{|c|}{15} & \multicolumn{2}{|c|}{30} & \multicolumn{2}{|c|}{60} & \multicolumn{2}{|c|}{120} \\
\hline & 36 & 113 & 36 & 113 & 36 & 113 & 36 & 113 & 36 & 113 & 36 & 113 \\
\hline$<0.01 \pm 0.00$ & 0 & 0 & 0 & 0 & 3 & 0 & 3 & 2 & 3 & 3 & 4 & 4 \\
\hline $0.3 \pm 0.03$ & 0 & 0 & 0 & 0 & 1 & 0 & 2 & 0 & 3 & 2 & 4 & 3 \\
\hline $0.6 \pm 0.03$ & 0 & 0 & 0 & 0 & 0 & 0 & 1 & 0 & 3 & 1 & 4 & 3 \\
\hline
\end{tabular}

${ }^{\mathrm{z}} 1 \mathrm{ppb}=1 \mu \mathrm{g} \cdot \mathrm{L}^{-1}$

${ }^{y}$ Visual evaluations were recorded on the day of the final treatment (day 36 ) and at the end of the 77 -d recovery period (day 113 , last harvest); $36=$ day 36 (final irrigation with topramezone-treated water); $113=$ day 113 (end of 77 -d recovery period after final irrigation with topramezone-treated water).

${ }^{\mathrm{x}} 0=$ no effect, $1=$ slight effect $(<10 \%$ leaves with symptoms $), 2=$ obvious symptoms $(10 \%$ to $50 \%$ leaves bleached $), 3=$ very obvious reduced growth $($ all leaves affected $), 4=$ all leaves necrotic. 
an earlier study we conducted that yielded an $\mathrm{EC}_{10}$ of $3.5 \mathrm{ppb}$ (Haller et al., 2017). 'Palmetto' st. augustinegrass grown in mixes with carbon contents of $1.5 \%$ or $4.0 \%$ carbon and irrigated with topramezone-treated water were not different from one another, but irrigation with $\geq 60 \mathrm{ppb}$ topramezone on plants grown in these substrates reduced growth by $25 \%$ to $30 \%$ compared with untreated controls. These treatments caused obvious damage to 'Palmetto' st. augustinegrass, but plants essentially recovered after the 77-d grow out period (Table 1). Plants that were grown in substrates with $0.3 \%$ or $0.6 \%$ carbon and irrigated with topramezone had reductions in growth that were intermediate between the no-carbon and high-carbon treatments (Fig. 4).

In summary, these experiments revealed that as concentrations of topramezone in irrigation water increased from 0 to $120 \mathrm{ppb}$, st. augustinegrass had higher injury and delayed turfgrass recovery when growing in sand with little to no organic matter. St. augustinegrass not only showed leaf bleaching but also exhibited stunted growth and reduced clipping production. However, as the concentration of soil carbon increased from $0 \%$ to $4 \%$, st. augustinegrass injury was ameliorated for all topramezone-irrigation treatments.

The use of irrigation water with topramezone concentrations $>10.1$ $\mathrm{ppb}$ can lead to greater plant injury and growth suppression for st. augustinegrass growing in sand with $<1.2 \%$ organic matter $(0.6 \%$ carbon $)$, whereas st. augustinegrass growing in sand with $>3 \%$ organic matter ( $1.5 \%$ carbon) tolerated being irrigated with water having higher topramezone concentrations. Therefore, turfgrass managers who rely on surface waters for irrigation may need to delay irrigation if topramezone is used for aquatic weed control in those waters, particularly if the substrate is sandy with low organic matter and concentrations of topramezone are expected to be greater than $10 \mathrm{ppb}$.

Andrew et al. (2003) conducted a similar study to evaluate the effect of soil organic matter on fluridone phytotoxicity to 'Floratam' st. augustinegrass. Their study used 'Floratam' st. augustinegrass grown on sand or sod

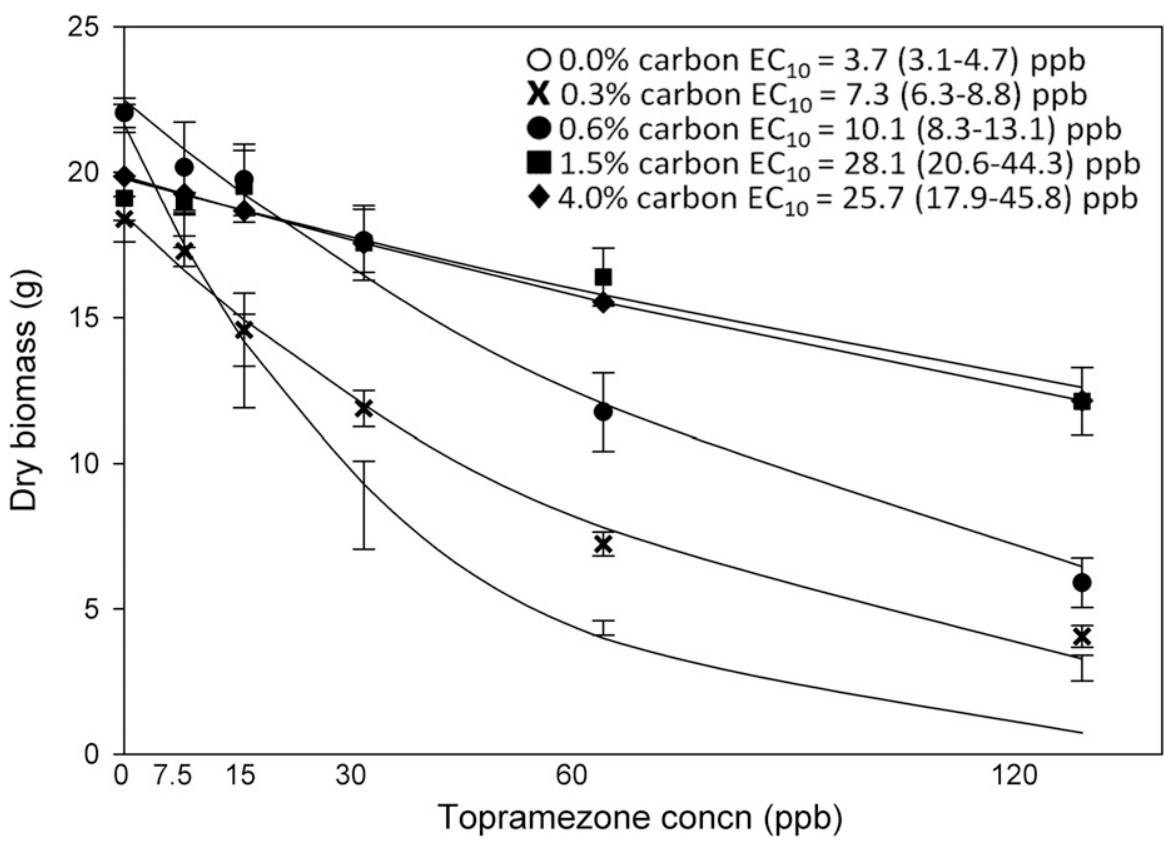

Fig. 4. Dry biomass of 'Palmetto' st. augustinegrass grown in sand amended with $0 \%, 0.3 \%, 0.6 \%, 1.5 \%$, or $4 \%$ carbon and irrigated eight times over a $36-\mathrm{d}$ period with $7.5,15,30,60$, or $120 \mathrm{ppb}$ of topramezone, followed by a 77 -d grow out period to evaluate delayed effects. Grass clippings were collected about every 2 weeks during the 117 -d study period; $\mathrm{EC}_{10}=$ effective concentration of topramezone ( $95 \%$ confidence intervals) that reduces biomass by $10 \%$ compared with untreated controls; $1 \mathrm{ppb}=1 \mu \mathrm{g} \cdot \mathrm{L}^{-1}, 1 \mathrm{~g}=0.0353 \mathrm{oz}$.

( $28 \%$ organic matter) overlaid on Arredondo fine sand containing 1.5\% organic matter and compared the response of these plants to fluridone in irrigation water. 'Floratam' st. augustinegrass was affected at $15 \mathrm{ppb}$ in sand culture, but was unaffected by eight times as much fluridone (120 ppb) when grown on sod with the higher organic content. The $K_{\mathrm{oc}}$ for fluridone ranges from 350 to $2460 \mathrm{~mL} \cdot \mathrm{g}^{-1}$, compared with topramezone's $K_{\mathrm{oc}}$ of 22-172 $\mathrm{mL} \cdot \mathrm{g}^{-1}$ (Shaner, 2014). The higher $K_{\mathrm{oc}}$ for fluridone may account for the ability of 'Floratam' st. augustinegrass to survive irrigation with higher rates of fluridone because more herbicide would be bound to organic matter in the substrate. It is interesting to note that in our experiments, there is also a nearly 8 -fold difference in topramezone $\mathrm{EC}_{10}$ values for plants grown in sand $\left(\mathrm{EC}_{10}=3.7 \mathrm{ppb}\right) \mathrm{com}$ pared with those grown in substrates with $1.5 \%$ carbon $\left(\mathrm{EC}_{10}=28.1 \mathrm{ppb}\right)$.

Topramezone is registered for postemergence weed control in cool-season grasses, e.g., the Pylex label lists a typical application rate of $37 \mathrm{~g} \cdot \mathrm{ha}^{-1}$ (BASF, 2015). The Pylex label also states that it should not be applied to st. augustinegrass unless control or suppression of this species is desired. The soil half-life of topramezone in terrestrial applications is $14 \mathrm{~d}$ (Shaner, 2014). The theoretical total amount of topramezone applied to 'Palmetto' st. augustinegrass in this study can be calculated using the surface area of each 7.5-inch-diameter pot and the total amount of active ingredient in the total amount of water applied to each pot over the course of eight irrigations. This calculation reveals that eight irrigations with $120 \mathrm{ppb}$ topramezone in 0.5 inch of water is equivalent to applying $49.4 \mathrm{ppb}$ topramezone over $36 \mathrm{~d}$. Therefore, it is not unexpected that noteworthy growth suppression or plant death occurred in our experiments despite being applied over a 36-d period because the Pylex label indicates that severe damage or control of st. augustinegrass will occur after a single application of $37 \mathrm{ppb}$ (BASF, 2015). St. augustinegrass should be irrigated with $0.5-0.75$ inch of water two to three times per week if no rainfall occurs (Trenholm et al., 2017); these experiments mimic this regime, so the results of these studies may predict field 
response of st. augustinegrass to irrigation with water containing $120 \mathrm{ppb}$ topramezone.

Topramezone is labeled for the aquatic market as Oasis ${ }^{\circledR}$. In addition to several other irrigation restrictions on the label, individuals using Oasis ${ }^{\circledR}$ are instructed to contact the registrant if water treated with $>30$ $\mathrm{ppb}$ of topramezone is to be used for irrigation of turf or ornamentals (SePRO Corporation, 2014). Netherland (2014) reported that topramezone is typically applied in whole-lake treatments at concentrations of 20 $40 \mathrm{ppb}$ and that submersed weed control requires more than $45 \mathrm{~d}$ of exposure. Toor and Shober (2009) reported that the relationship of soil carbon content to total organic matter is a ratio of $1: 2$ because carbon accounts for $\approx 50 \%$ of the total weight of the carbon, hydrogen, and oxygen that typically comprise soil organic matter. These factors, along with the calculated $\mathrm{EC}_{10}$ value of $>10.1 \mathrm{ppb}$ for topramezone applied to 'Palmetto' st. augustinegrass in soils with $\leq 0.6 \%$ carbon, should be a concern for aquatic plant managers because most soils in Florida contain $<3.0 \%$ organic matter, which is equivalent to $1.5 \%$ carbon (Toor and Shober, 2009).

Topramezone applied to 'Palmetto' st. augustinegrass in irrigation water in these studies caused the typical bleaching and reduced growth characteristic of HPPD inhibitors.
The recovery of plants exhibiting these symptoms at day 36 was in progress for most treatments after the 77-d grow out period (Table 1 ). These data suggest that if irrigation with topramezone-treated water is discontinued soon after phytotoxicity is noticed, it is likely that 'Palmetto' st. augustinegrass will recover after a few weeks of irrigation with untreated water.

\section{Literature cited}

Andrew, W., W.T. Haller, and D.G. Shilling. 2003. Response of st. augustinegrass to fluridone in irrigation water. J. Aquat. Plant Mgt. 41:61-63.

BASF. 2012. Armezon ${ }^{\mathrm{TM}}$ herbicide label. 21 Apr. 2017. <http://www.agproducts. basf.us/products/label-and-msds / armezon-herbicide-label.pdf>.

BASF. 2013. Frequency ${ }^{\circledR}$ herbicide label. 19 Apr. 2017. <http://www.cdms.net/ LDat/ld95S012.pdf>.

BASF. 2015. Pylex ${ }^{\mathrm{TM}}$ herbicide label. 21 Apr. 2017. <http://www.cdms.net/ ldat/ldB65006.pdf>.

Haller, W.T., L.A. Gettys, and T. Uchida. 2017. Effects of topramezone and bispyribac-sodium in irrigation water on warm-season turfgrasses. HortTechnology 27:599-606.

Koschnick, T.J., W.T. Haller, and G.E. MacDonald. 2005. Turf and ornamental plant tolerances to endothall in irrigation water. I. Ornamental species. HortTechnology 15:318-323.
Netherland, M.D. 2014. Chapter 11: Chemical control of aquatic weeds, p. 7188. In: L.A. Gettys, W.T. Haller, and D.G. Petty (eds.). Biology and control of aquatic plants: A best management practices handbook. 3rd ed. Aquatic Ecosystem Restoration Foundation, Marietta, GA.

Puri, A., W.T. Haller, and M.D. Netherland. 2009. Cross-resistance in fluridone-resistant hydrilla to other bleaching herbicides. Weed Sci. 57:482-488.

Senseman, S. (ed.). 2007. Herbicide handbook. 9th ed. Weed Sci. Soc. Amer., Lawrence, KS.

SePRO Corporation. 2014. Oasis ${ }^{\circledR}$ herbicide label. 12 July 2017. <http://www. sepro.com/documents/Oasis_Label. pdf $>$.

Shaner, D.L. (ed.). 2014. Herbicide handbook. 10th ed. Weed Sci. Soc. Amer., Lawrence, KS.

Toor, G.S. and A.L. Shober. 2009. Soils and fertilizers for master gardeners: Soil organic matter and organic amendments. Univ. Florida, Inst. Food Agr. Sci. Publ. SL273. 14 Apr. 2015. <https://edis.ufl. $\mathrm{edu} / \mathrm{mg} 454>$.

Trenholm, L.E., J.L. Cisar, and J.B. Unruh. 2017. St. augustinegrass for Florida lawns. Univ. Florida, Inst. Food Agr. Sci. Publ. ENH5. 22 Apr. 2017. <https://edis.ifas. ufl.edu/lh010>.

Trenholm, L.E., J.B. Unruh, and J.L. Cisar. 2014. Watering your Florida lawn. Univ. Florida, Inst. Food Agr. Sci. Publ. ENH9. 22 July 2017. <https://edis.ifas.ufl.edu/ lh025>. 